\title{
虚遷移構造による有機反応の記述. コンピュータ指向の新しい表現法
}

\author{
Imaginary Transition Structures. A Novel Approach to Computer- \\ Oriented Representation of Organic Reactions.
}

藤 田 眞 作**

Shinsaku FuJITA*

\begin{abstract}
An imaginary transition structure (ITS) is defined as a kind of structure that has par-, out-, and in-bonds in accord with structural changes during an organic reaction. Various subgraphs (or substructures) of an ITS afford effective pieces of information on reaction types. Thus, imaginary rings in an ITS are the descriptors of ring-opening, ring-closure, and rearrangement reactions. Three- and four-nodal subgraphs correspond to reaction-site changes. Other useful concepts such as reaction-center graphs, reaction graphs, and reaction strings are also discussed. An algorithm for selecting an essential set of essential rings is proposed. The first method for giving a canonical name to ITS is presented. Enumeration of reaction types is also discussed.
\end{abstract}

\section{1. はじめに}

コンピュータで有機反応を取り扱うという観点から, 筆者はすでに本誌上で, 従来の有機反応の表現法の解説 を行った1)。そこでは, 従来の表現法が,「構造十反応 型式」パラダイムにとらわれていることを述べ，総合的 なコンピュータシステム構築のためにはこのパラダイム から脱却する必要があるとした。筆者はこの方針に沿っ た新しい表現法として虚遷移構造 (Imaginary transition structures. 以後 ITS と略す) を提案し，ここ数年来その 展開を図っている ${ }^{120)}$ 。本報では，これまでに得られた 成果をまとめて報告する。

有機反応を記述するには, その目的によっていろいろ なレベルがある。本報では，有機反応とは「有機構造に おける結合の組み換え」であるとみなす。この立場は， 有機合成を目的としていることから来るものである。例 えば，「置換反応」は考えるが「 $\mathrm{S}_{\mathrm{N}} 2 」 は$ 記述の対象からは ずすことになる。なぜなら, 後者は有機反応機構の範囲

* 富士写真フィルム (株) 足柄研究所

* Research Laboratories, Ashigara, Fuji Photo Film Co., Ltd.
でのみ有効であるからである。このように立場を限定し ても,有機反応の表現には様々なむずかしい問題がある。 スキーム 1 は, テトラヒドロフランの開環反応を示し たものである。この反応は, ブロム化であると言うこと

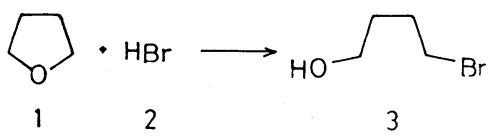

Scheme 1

もできる。また，置換反応という総称で呼ぶこともでき よう。ここで，スキーム 1 を開環反応とするには，どの ような認識過程を経るのであろうか。まず出発系に 5 員 環が存在することと生成系に 5 員環がないことを認識 し，ついで両辺を比較して，やっと開環反応であること を特定するのである。一方，スキーム1をブロム化とみ なすには, 出発系の $\mathrm{C}-\mathrm{O}$ 結合が切れて, 一方は $\mathrm{OH}$ と なり他方は C-Br となることを認識する必要がある。

有機化学者はこのような認識をいとも簡単にやっての けるが, コンピュータにこのような判断を行わせるのは かなりむずかしい。特に，スキーム1のような反応式を 使用する場合は, 出発系と生成系の各原子の対応をどの ようにつけるかという問題が出て来る。 
同じ反応をスキーム 2 のように表現したとしよう。こ のとき両者を同じであると認識することは，すこし考え

$$
\left(\int_{4}^{\left(\mathrm{CH}_{2}\right)_{4}} \cdot \mathrm{HBr} \rightarrow \underset{5}{\mathrm{HO}\left(\mathrm{CH}_{2}\right)_{4} \mathrm{Br}}\right.
$$

Scheme 2

れば上記の例以上にむずかしいことが了解できるであろ う。即ち出発系の 1 と 4 , 生成系の 3 と 5 が同じもので あると判断することなど幾重にも複雑な操作をしなけれ ばならない。ここでも有機化学者の思考をコンピュータ でおきかえることのむずかしさが痛感される。

スキーム 1,2 のような反応式は, 有機化学では標準的 な表現法である。多くのコンピュータシステムは当然の ことながらこの表現法を基礎においている。従って，上 記の困難を背負い込むことになる。これを回避するため に様々な工夫が行われていることは前回の総説 ${ }^{1)}$ で解説 した通りである。

本報の「虚遷移構造」は, これらの困難を根本から克服 しょうとする一つの試みである(注1)。

\section{2. 虚遷移構造2)}

虚遷移構造 (imaginary transition structure ITS) とは, 三種の結合一一恒結合 (par-bond), 出結合 (out-bond) および入結合 (in-bond)——よって，原子または原子 団を結んだ構造である。このように定義したITS は， 通常の反応式で表わされる情報を包含している。例えば,
図 1 左はITS の構成を図示したものである (カラーロ絵 参照)。出発系 $(\mathrm{S})$ と生成系 $(\mathrm{P})$ とを, 原子と原子の対 応を付けた上で重ね合わせ，反応で変化しない結合を恒 結合 (一三たは黒色の結合) とし, 切断される結合を出 結合 (一または赤色の結合) とし, 生成する結合を入結 合 (一のまたは緑色の結合) として, 区別すると, ITS ( 7) が生ずる注2)。生じた ITS（７）は一種の構造式である。こ れまで $\mathrm{S} \rightarrow \mathrm{P}$ の変化としてとらえていたものを, ここで は静的な構造式(ITS) とみなすわけである。このように 思考を転換すると，これまであいまいに使用して来た有 機反応に関する言葉にはっきりした定義を与えることが できる注3)。

ITS から反応式を誘導するために, 出発系への投影 (projection to starting stage 略称 PS) および生成系へ の投影 (projection to product stage 略称 PP) を考える (図 1 右)。PS 操作は ITS から入結合(一-)を削除する操 作である。この結果, 出発系が生ずる。一方 PP は, ITS から出結合 (サ) を削除する操作であり, 生成系を 発生させる。試みに, 図 1 に PS, PPを施すと, S およ びPが生ずることが確められる。

ITS にあらわれる結合は，上記の三種の結合を組み合 せたものであり，表 1 に示す 15 種が存在する。これら を総称して虚結合 (imaginary bond) と言う。ITS をコン ピュータで取り扱うためには，虚結合をコード化する必 要がある。この目的で, 各虚結合に複素結合数 (complex bond number 略称 CBN) を対応させる。これは一対の 整数 $(\mathrm{a}$ b)であり, $\mathrm{a}$ は出発系における結合の多重度, b は生成系の多重度から出発系の多重度を差引いたものを

Table 1 Imaginary bonds classified to type A, B, and C bonds ${ }^{2.13)}$.

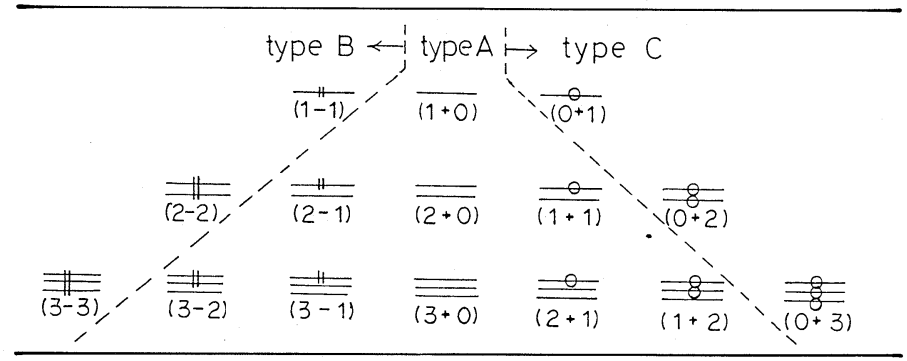

注 1）本総合論文では, 紙幅の関係もあり, 他の方法との比較は十分に行 えなかった。それぞれの長所短所は，原報1 20)に詳述してあるので， 参照されたい。また, この分野の全般的な知識を得るためには, 巻末 にあげた参考書 ${ }^{26)}$ が最適である。

注 2）ITS をカラーディスプレイ上に表示するには，例えば，恒結合を白 抜の実線，入結合を緑色の実線，出結合を赤色の実線とすればよい。 実際に行うと, 本文で用いた黒白表示よりも格段に分かりやすい描画 が得られる。カラーロ絵参照。本稿本文では出版コストを考えて黒白 表示にとどめた。
注 3）この「思考の転換」を意識的に行っているかどうかが、「構造十反応 型式」パラダイムを克服したかどうかの分岐点となる。「思考の転換」 が行われているかどうかは次の諸点を問うてみるとよい。(a) 上記三 種の結合を実体として考えているか(一種の結合が切断あるいは生成 すると考えるのでは不十分である)。( b ) 虚結合に, CBNのような一 組の (統合された) 表現を明示的に与えているか。(c)反応緒とくに二 本緒以上の認識があるかどうか。(d)PS，PPのようなITSを図形(構 造式)とみなす操作が定義されているか。(e) 環構造とくに転位橋 (BR)の認識があるかどうか。(f) 正準名の存在。 

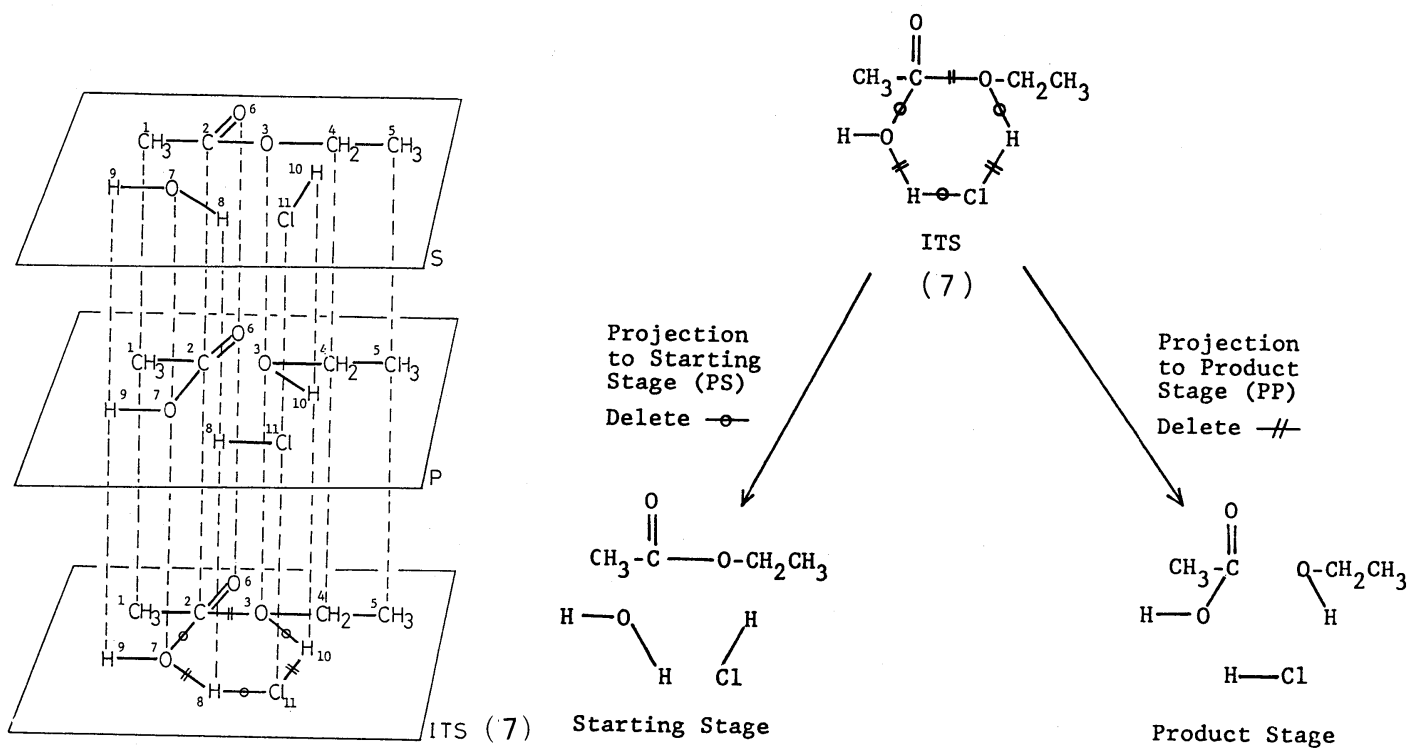

Fig. 1 The Constitution of imaginary transition structures (ITS's) (left) and projection to starting stage and to product stage (right) ${ }^{2)}$.

This example is the hydrolysis of ethyl acetate catalyzed by hydrochloric acid. The abbreviations, " $\mathrm{S}$ " and "P", correspond to the starting and product stage, respectively.

Table 2 The connection table of ITS $^{\text {a }}$.

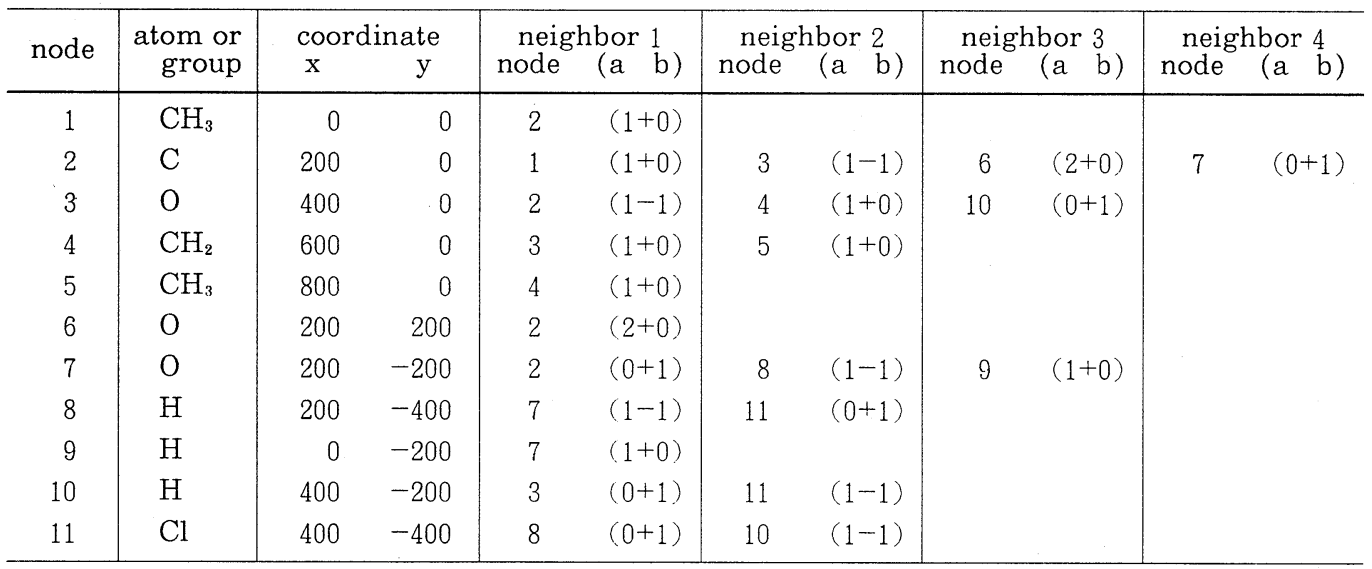

${ }^{a}$ The numbering of nodes is given in Fig 1.'

表わす。表 1 には複素結合数 (CBN) も併せて示した注4。 このように定義したCBN を用いると, 図 1 のITS(7) は, 表 2 のようなITS 結合表 (ITS connection table, 略称 ITS-CT)の形でコンピュータに格納することがで きる。表 2 は若干の圥長さを含んでいるが以後の議論に

\footnotetext{
注 4） $\mathrm{CBN}(\mathrm{a} \quad$ b) のbは，反応緒のコード化において，+一が交互に出現 するように定義したものである。CBN のかわりに他の整数の組を用 いることも可能である。
}

用いるには便利である。実際のコンピュー夕利用のため には, 圥長さを除いたデー夕構造にする必要があるが, ここでは論じない。

\section{3. 反応中心グラフ，反応緒 ${ }^{2}$}

前項でITSには，反応式に含まれる情報が完全に包 含されていることが明らかになった。これにとどまらず, ITS の中には，反応に関する情報が詰まっている。これ 
らの情報は, ITS の部分構造 (substructure) あるいは部 分グラフ (subgraph) として取り出すことができる。

有機反応を ITS の形で書くと，その反応中心 (reaction center) は容易に識別される。即ち, 反応中心とは出結 合および/または入結合が接合した節点(node)のことで ある。ITS から反応中心を取り出し, さらにそれらを結 ぶ虚結合も取り出すとする。このようにして得られた ITS の部分グラフを, 反応中心グラフ (reaction-center graph 略称 RCG) と呼ぶ。例えば, ブタジエンと無水マ レイン酸の Diels-Alder 反応を表わす ITS ( 8) からは, RCG (9) が取り出せる (図2)。この RCG は, 一般に Diels-Alder 反応 (すべての反応中心は炭素原子) を表現 している。

RCG の節点の原子の種類を問わないことにすれば, さらに抽象度の上がったグラフ(これを反応グラフ reaction graph ; 略称 RG という)が得られる。 RCG (9) から得られる RG (10) は, 一般に $[4+2]$ 付加 (各節点を 抽象的に球であらわす)を指す。

RG から, 含まれる恒結合を消去すると, 正味の電子 移動を表わす基本反応グラフ (basic reaction graph, 略称 BRG) が得られる。例えば, RG (10) から BRG (11) を得る。

得られた RCG，RG，BRG は，それぞれにPS，PP 操 作を施すことによって，対応する反応式に変換できる。 このように通常の反応式で行われていた反応型式の分類 は, ITS の世界では, 種々のレベルの部分グラフを取り 出すことで達成されるわけである。

図 2 の ITS ( 8), RCG (9), RG (10) および BRG (11) を調べると, すべての図形に, 出結合と入結合が交互に 出現することが分かる。このように, 出結合と入結合が 交互に現われる部分構造を反応緒 (reaction string; 略称 RS) と呼ぶ。有機電子論において, 反応式の各構造式に 円弧の矢印を用いて電子の動きを表示する手法が広く普 及している。この円弧の矢印と反応緒が関係しているこ とは有機化学を学んだ者ならば誰しも気付くことであ る。有機電子論では矢印の向きは重要である。しかし,

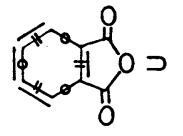

ITS 8

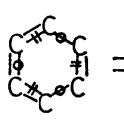

RCG 9

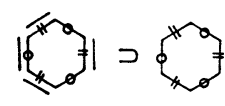

RG 10
BRG 11

Fig. 2 Subgraphs of ITS 8 .

注 5）電子移動の矢印の向きは, 化学者の思考に委ねる。ただし, 結合の 両端の原子の電子陰性度を比較して，矢印を付すアルゴリズムを作る こともできよう。
Diels-Alder 反応のように一義的に決まらない場合もあ り，またどちらにつけるか迷うことも多い。ITS の取り 扱いでは，この矢印の方向を無視する。これは有機反応 を「有機構造における結合の組み換え」であるとみなした ことから当然の態度である。この取り扱いは有機化学者 にとって退歩のように見えるかも知れない。しかし, 反 応緒というコンピュータで扱いやすい概念を与えるとい う点で十分にあがなわれる注5)。

さらにスキーム 3 のような反応を取り扱う場合に,

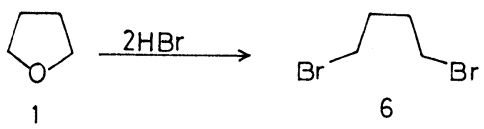

Scheme 3

ITSの立場の独自性が出る。この反応はスキーム 1 の生 成物である 3 がさらにブロム化されたとみなせる。この ように考えて各段階で電子移動の矢印を付すことは可能 である。しかしスキーム3のように多段階を一まとめに した反応式に矢印を付すことにはうしろめたいところが ある。ITS (12) はスキーム3の反応に対応するものであ るが, この表現はITS の定義から極く自然に出て来る。

ITS (12) からは, 上と同様に各部分グラフを取り出せ る (図 3)。ここで, 反応緒は二本存在するとみなす。即 ち，CBN を用いて表現すれば， 1 O $(1-1) 2 \mathrm{C}(0+1) 6$ $\mathrm{Br}(1-1) 7 \mathrm{H}(0+1) 10$ および $1 \mathrm{O}(1-1) 5 \mathrm{C}(0+1) 8 \mathrm{Br}$ $(1-1) 9 \mathrm{H}(0+1) 10$ が反応緒である ${ }^{\text {注4)。 }}$

以上の議論から, ITS に含まれる反応緒の数によって 反応を分類できることが分かる。反応緒の数に応じて一 本緒反応 (one-string reaction), 二本緒反応 (two-string reaction) ……と称することにする。

偶数員環の一本緒反応 ${ }^{3)}$, 奇数員環の一本緒反応 ${ }^{4}$, 二本緒反応 ${ }^{7,8)}$ の例をとりあげてその種々相を論じた。 本報では詳しく触れないが, 興味のある方は原報を参照

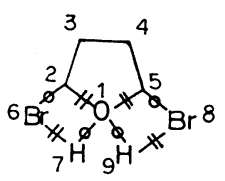

ITS 12

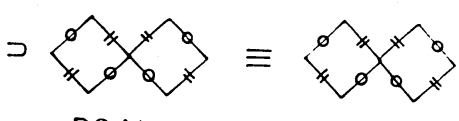

RG 14

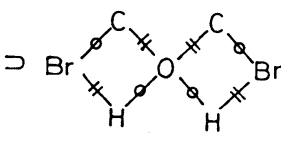

RCG 13

BRG 15
Fig. 3 Subgraphs of ITS 12 . 
していただきたい。ことに二本緒反応には，有機合成の 面で重要な著名反応 (Name reactions) が含まれている。 これらの二本緒反応は, 従来の方法では十分に取り扱え なかったものである。

\section{4. 環構造 $2,13,14$}

ITS に含まれる環を，虚環 (imaginary ring)あるいは ITS 環と総称する。虚環は, 反応情報の重要な記述子で ある。虚環を分類するために, 表 1 の虚結合を三つのカ テゴリーに分ける ${ }^{13)}$ 。タイプ A 結合とは，その CBN (a b) が $\mathrm{a} \neq 0$ かつ $\mathrm{a}+\mathrm{b} \neq 0$ であるものをいう。言い換えれ ば少なくとも一本の恒結合を含むような虚結合をタイプ $\mathrm{A}$ 結合という。タイプ B 結合とは, (a b ) が $\mathrm{a}+\mathrm{b}=0$ を満たすような結合を指す。タイプ C 結合は $\mathrm{a}=0$ の場 合である。

表 3 に虚環の分類を示す ${ }^{13)}$ 。 $\mathrm{BO}_{\mathrm{m}}$ は, $\mathrm{m}$ 次開環橋 (bridge of ring-opening of order $\mathrm{m}$ )の略号であり, 後 程論ずるように開環反応を示す。 $\mathrm{BC}_{\mathrm{n}}$ は, $\mathrm{n}$ 次閉環橋 (bridge of ring-closure of order $n$ )であり, 開環反応 に対応する。BR は，転位橋 (bridge of rearrangement) を略したもので，転位反応を示す記述子となる。IR は 不変環 (invariant ring)である。これらの虚環の分類は, ITS から環構造を検出し，これに含まれる夕イプ A C C 結合の数を数えた後, 表 3 に従えば容易に行える。

図 3 の ITS (12) には, 5 員環の $\mathrm{BO}_{2}$ (環 1-2-3-4-5) が 含まれている。この $\mathrm{BO}_{2}$ がテトラヒドロフランの開環 反応に対応していることは明らかであろう。

図 2 の ITS (8) は, 6 員環の $\mathrm{BC}_{2}$ を含む。これは Diels-Alder 付加の本質である 6 員環形成をグラフ的に 表現している。ITS（8)には反応で変化しない 5 員環が 存在し, これは, IR として分類される。このほか 9 員 環の $\mathrm{BC}_{2}$ も存在するが, これについては後に論ずるこ とにしよう。

ITS 法が他の方法に比較して有利な点の一つは, BR
の存在に注目したことに由来する。 $\mathrm{BO}_{\mathrm{m}}$ や $\mathrm{BC}_{\mathrm{n}}$ がそれ ぞれ出発物や生成物にも実際の環として出現するのに対 して，BR はITS だけにしか存在しない環である。転位 反応を通常の反応式から認識することは非常に複雑な操 作が必要である。これに対して, ITS 法では単に BR を 検出するという操作で済むのはコンピュータシステム構 築の際に大きな利点となる ${ }^{10)}$ 。

例えばスキーム 4 はピナコール転位の例を示したもの

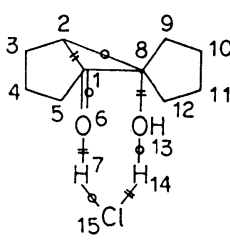

ITS 18

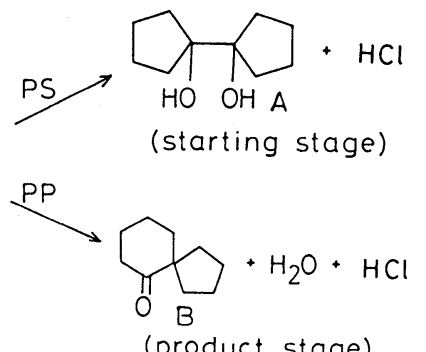

(product stage)

\section{Scheme 4}

である。この反応はITS (18)で表現される。このITS の 中には, BR として三員環の1-2-8が含まれている。こ の BR はピナコール転位が 1,2 移動であることに対応し ている。ITS (18)には 5 員環の $\mathrm{BO}_{1}(1-2-3-4-5)$ および 6 員環の $\mathrm{BC}_{1}$ (1-8-2-3-4-5) が含まれる。これらの虚環は, この反応が 5 員環から 6 員環への環拡大を伴うピナコー ル転位であることを見事に表現している。

このようにITS 法にとって BR の概念は重要であるの で，いろいろな転位反応について BR の存在を確めた。 詳しくは原報 ${ }^{10)}$ を参照されたい。

次に ESER (essential set of essential rings)につい て説明する ${ }^{13)}$ 。既にITS ( 8 )において，9員環の $\mathrm{BC}_{2}$ が 存在することを述べた。しかし， 6 員環 $\mathrm{BC}_{2}$ と 5 員環 IR を取り出しておけば， 9 員環 $\mathrm{BC}_{2}$ は採用しなくてよ

Table 3 Ring types appearing in $\operatorname{ITS}^{13)}$.

\begin{tabular}{c|c|c|c|c|c}
\hline \multirow{2}{*}{ ring type } & \multirow{2}{*}{ size } & \multicolumn{2}{|c|}{ number of imaginary bonds } & \multirow{2}{*}{ remarks } \\
\cline { 3 - 5 } & & type A & type B & type C & \\
\hline \multirow{2}{*}{$\mathrm{BO}_{\mathrm{m}}$} & $r$ & $r-m$ & $m$ & 0 & $m \geqq 1$ \\
$\mathrm{BC}_{\mathrm{n}}$ & $r$ & $r-n$ & 0 & $n$ & $n \geqq 1$ \\
$\mathrm{BR}$ & $r$ & $r-2$ & 1 & 1 & \\
$\mathrm{IR}$ & $r$ & $r$ & 0 & 0 & \\
trivial & $r$ & $r-m-n$ & $m$ & $n$ & $m+n>2, m n \neq 0$ \\
\hline
\end{tabular}




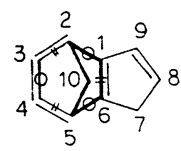

$19-1\left(B C_{2}\right)$

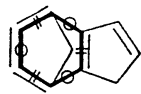

$19-4\left(B C_{2}\right)$

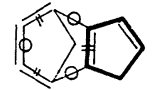

$19-2(I R)$

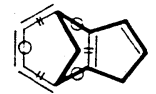

$19-5\left(B C_{2}\right)^{*}$

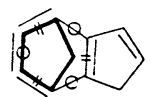

$19-3(I R)$

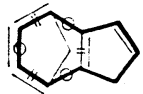

$19-6\left(B_{2}\right)^{*}$
Fig. 4 Rings in ITS (19). Rings with* are tied rings ${ }^{13)}$.

い。図 4 のITS (19)には，6 個の環が含まれている。こ のうち, 情報として必要なのは 5 員環 $\mathrm{BC}_{2}(19-1), 5$ 員 環 IR 2 個 (19-2 および 19-3) および 6 員環 $\mathrm{BC}_{2}$ (19-4)で ある。このほか 8 員環と 9 員環の $\mathrm{BC}_{2}$ があるが取り出 す必要はない。このような選択は，一体どのようなアル ゴリズムによって可能なのであろうか。

$\mathrm{ESER}^{13)}$ では，採用しなくてもよい環として，結束環 (tied ring) ${ }^{\text {i氵6) }}$, 多重結束環 (multi-tied ring) 抒よび従属 環 (dependent ring)を定義した。これ以外の環が ESER に含まれる。詳しくは原報 ${ }^{13)} に$ 譲るが, 情報として有効 なものを残す方法として応用範囲が広い。

ESER 法は，通常の有機構造においても有効である ${ }^{14)}$ 。 化合物 (20)には 12 個の環が含まれる。このうち ESER は，Oで囲んだ 6 個の環を採用する(図 5)。この分野で 著名な SSSR 法 (the smallest set of smallest rings) ${ }^{21)}$ で

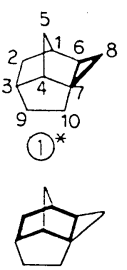

(5)

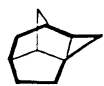

9

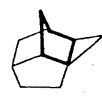

(2) ${ }^{*}$

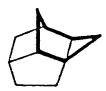

6

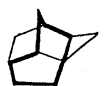

10

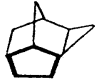

(3)*

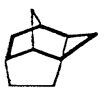

7

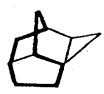

11

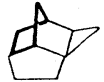

(4) *

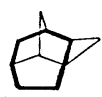

(8)

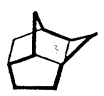

12
Fig. 5 Twelve rings detected from compound 20 . The rings encircled belong to ESER. The rings marked by asterisks are of $\mathrm{SSSR}^{14)}$.

注 6）縮合環を，観点を変えて定義したもの。例えば，5-6 縮合環の場合 は, 外周の 9 員環を主体にして, これが中途でしばられている(結束 されている)とみなす。
は，*印を付した 4 個の環が採られる。従来，合成化学 の面から見た有用な環を取り出すためのアルゴリズムは 数多く提案されているが，いずれも ad hoc 的な約束を 含んでいる ${ }^{22)}$ 。筆者らの ESER は比較的簡単なアルゴリ ズムであるのにかかわらず，有機化学者の直観に沿った 結果を与える。

\section{5. $\mathrm{n}$ 節部分グラフ ${ }^{5,12)}$}

第3 項で反応中心グラフについて述べた。これは，関 与する反応中心をすべて含む部分グラフである。この中 には，さらに有用な部分グラフが内包されている ${ }^{5,12) 。}$ 例えば，スキーム 5 に示した反応(脱クロル化)を考えて

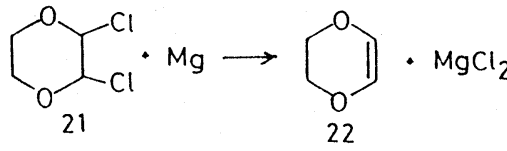

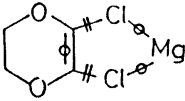

ITS 23

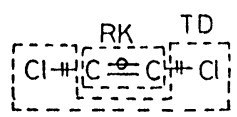

24
Scheme 5

みよう。このスキームに対応するITS (23) から反応に関 与する炭素原子 2 個と，それらに結合している塩素原子 を取り出す。このような 4 個の節点からなる部分グラフ (24)を四節部分グラフ (four-nodal subgraph) という。 24 にP，PP 操作を施すと，これが脱クロル化のグラ フ的な表現になっていることが分かる (PS : Cl-C-C-Cl, $\mathrm{PP}: \mathrm{Cl}+\mathrm{C}=\mathrm{C}+\mathrm{Cl})$ 。

四節部分グラフを，さらに細分して反応核 (reaction kernel 略称 RK) と末端記述子 (terminal descriptor 略称 TD）を定義する ${ }^{12)}$ 。24 の場合， RK は $\mathrm{C}=\mathrm{C}\left(=\mathrm{K}_{\mathrm{e}}\right)$, TD は $\mathrm{Cl}-\mathrm{H}-\mathrm{K}_{\mathrm{e}}+\mathrm{Cl}$ である。前者は, 二重結合生成に対応 しており, 後者は文字通り脱クロル化に対応している。 スキーム 5 の反応を考える場合, 通常脱クロル化あるい は脱離のみを記述する。この時二重結合生成は暗黙の了 解事項となっていたことが，RK の形で情報を取り出す とはっきりするわけである。このことはITS 法の図ら ざる成果である。

図 6 に示すように, $\mathrm{Cl}$ (塩素) < $\mathrm{Hal}$ (ハロゲン原子 $)<Z$ （電子吸引性原子） $<\mathrm{A}$ (任意原子)なる階層を考えてみよ う。これに伴って，TD が階層化される ${ }^{12)}$ 。例えば Hal

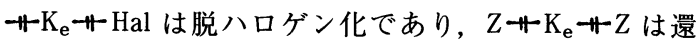
元的な脱離を表わしている。このようにややもすると 別々に理解しがちな概念が, 体系的な知識として整理で 
きる。図6のような階層を表現するために，生物学で使 われる用語を援用する。即ち, 門 (phylum), 網 (class), 群 (division). 節 (section), 目 (order), 科 (family), 属 (genus), 種 (species) である。例えば CもC 群あるいは $\mathrm{C}(1+1) \mathrm{C}$ 群のように用いることにしよう。

\begin{tabular}{|c|c|c|c|}
\hline level & clue & example & $\begin{array}{l}\text { natural } \\
\text { language term }\end{array}$ \\
\hline phylum & stringity & one-string & \\
\hline class & $\begin{array}{l}\text { no. of } C \text { atoms } \\
\text { in a reaction } \\
\text { kernel }\end{array}$ & $C_{2}$ & \\
\hline
\end{tabular}

division reaction kernel $\quad c=c$ formation of $\left(=K_{e}\right) \quad$ a double bond

\begin{tabular}{|c|c|c|c|}
\hline section & $\begin{array}{l}\text { terminal } \\
\text { descriptor }\end{array}$ & $A+K_{e} \# A$ & elimination \\
\hline order & $\begin{array}{l}\text { terminal } \\
\text { descriptor }\end{array}$ & $Z+\frac{k+Z}{e}$ & $\begin{array}{l}\text { reductive } \\
\text { elimination }\end{array}$ \\
\hline family & $\begin{array}{l}\text { terminal } \\
\text { descriptor }\end{array}$ & $\mathrm{Hal} * \mathrm{~K}_{e}-\mathrm{Hal}$ & $\begin{array}{l}\text { dehalogenation } \\
\text { (dihalo-elimn.) }\end{array}$ \\
\hline gen & $\begin{array}{l}\text { terminal } \\
\text { descriptor }\end{array}$ & $\mathrm{Cl}+\mathrm{K}_{e}+\mathrm{Cl}$ & $\begin{array}{c}\text { dechlorination } \\
\text { (dichloro-elimn.) }\end{array}$ \\
\hline
\end{tabular}

species ITS ITS 23

Fig. 6 Systematic classification of organic reactions by subgraphs of ITS ${ }^{12)}$.
三節部分グラフ (three-nodal subgraph) も同様にし て定義する ${ }^{5,12)}$ 。図 7 にH $(1-1) \mathrm{C}(0+1) Z$ 目に属する

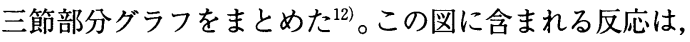
すべて酸化的な置換反応である。原報 ${ }^{12)}$ には， $Z(1-1)$ $\mathrm{C}(0+1) \mathrm{HH}$ 目 (還元的置換反応) および $Z(1-1) \mathrm{C}(0+1)$ $Z$ 目 (酸化状能不変の置換反応) の階層図が示されてい る。これらの上位概念は $\mathrm{A}(1-1) \mathrm{C}(0+1) \mathrm{A}$ 節 (置換反 応）となる。

目のレベルの三節部分グラフおよび四節部分グラフを 表 4〜6にまとめた5)。簡単のため HH (超水素 hyperhydrogen)のかわりにH と省略してある。比較のた め, Hendrickson のコード23)を併記した。三節部分グラ フと Hendrickson のコードとの対応は一見して明らかで ある。四節部分グラフの場合には, Hendricksonのコー ドとの方法論の相異のためにかなり異なったものとな る。この点については原報)で詳述したので繰返さない。

五節以上の部分グラフも同様に定義できる ${ }^{12)}$ 。この場 合 TD は, 奇数員数および偶数員数の部分グラフでそれ ぞれ共通となる。この事実は, 反応緒の交互性に由来す る。例えば，付加と共役付加とは，RK は異なるが TD は共通となる。通常両者の共通性を論ずることがあるが, ITS 法ではTD が同一であるということに置換えられる わけである。

\section{ITS の正準名 ${ }^{15)}$}

化合物を取り扱うコンピュータシステムにおいては, 正準名 (キャノニカル名; canonical name) が重要な役割

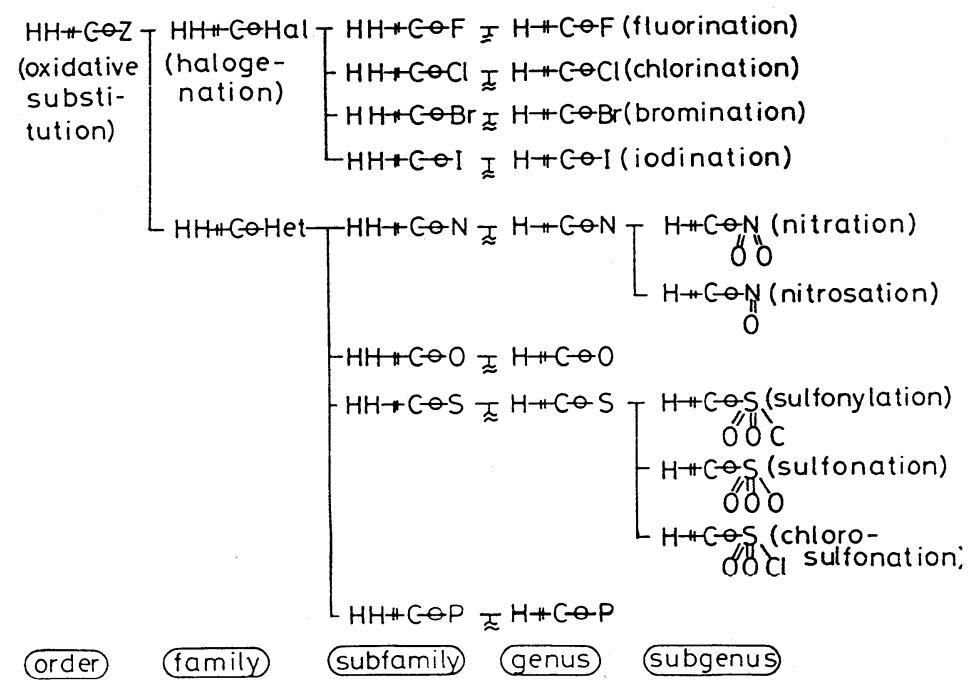

Fig. 7 Reaction hierarchy of $\mathrm{HH}(1-1) \mathrm{C}(0+1) Z$ order $^{12)}$. 
Table 4 Eliminations and additions represented by Four-Nodal subgraphs ${ }^{5)}$.

\begin{tabular}{|c|c|c|c|}
\hline $\begin{array}{l}\text { Four-Nodal } \\
\text { Subgraph }\end{array}$ & Code & Name of Type & $\begin{array}{l}\text { Hendrickson's } \\
\text { Code }\end{array}$ \\
\hline Eliminations : & & & \\
\hline $\mathrm{H}-\mathrm{H}=\mathrm{C}=\mathrm{C}-\mathrm{H}$ & $\mathrm{H}(1-1) \mathrm{C}(1+1) \mathrm{C}(1-1) \mathrm{H}$ & Oxidative elimination & $\Pi \mathrm{H}, \Pi \mathrm{H}$ \\
\hline $\mathrm{H}-\mathrm{H}=\mathrm{C}=\mathrm{C}-\mathrm{Z}$ & $\mathrm{H}(1-1) \mathrm{C}(1+1) \mathrm{C}(1-1) \mathrm{Z}$ & Isohypsic elimination & \\
\hline $\mathrm{H} \rightarrow \mathrm{C}=\mathrm{C} \pm \mathrm{Z}$ & $\mathrm{H}(1-1) \mathrm{C}(1+1) \mathrm{C}(2-1) \mathrm{Z}$ & Isohypsic $\pi$-rearrangement (eliminative) & $\Pi \mathrm{H}, \Pi \mathrm{Z}$ \\
\hline $\mathrm{H}+\mathrm{c}=\mathrm{C} \equiv \mathrm{Z}$ & $\mathrm{H}(1-1) \mathrm{C}(1+1) \mathrm{C}(3-1) \mathrm{Z}$ & Isohypsic $\pi$-rearrangement (eliminative) & \\
\hline$z+c=c-z$ & $Z(1-1) C(1+1) C(1-1) Z$ & Reductive elimination & \\
\hline$z+c \theta c \pm z$ & $\mathrm{Z}(1-1) \mathrm{C}(1+1) \mathrm{C}(2-1) \mathrm{Z}$ & Reductive $\pi$-rearrangement & \\
\hline$z+c \theta c \# z$ & $\mathrm{Z}(1-1) \mathrm{C}(1+1) \mathrm{C}(3-1) \mathrm{Z}$ & Ditto & \\
\hline$z \# c=c \# z$ & $\mathrm{Z}(2-1) \mathrm{C}(1+1) \mathrm{C}(2-1) \mathrm{Z}$ & Ditto & $\Pi \mathrm{Z}, \Pi \mathrm{Z}$ \\
\hline$z \# c \stackrel{\theta}{*}=2$ & $\mathrm{Z}(2-1) \mathrm{C}(1+1) \mathrm{C}(3-1) \mathrm{Z}$ & Ditto & \\
\hline$z \# c=c \triangleq z$ & $\mathrm{Z}(3-1) \mathrm{C}(1+1) \mathrm{C}(3-1) \mathrm{Z}$ & Ditto & \\
\hline Additions : & & & \\
\hline $\mathrm{H} \rightarrow \mathrm{C}=\mathrm{C}-\mathrm{O}-\mathrm{H}$ & $\mathrm{H}(0+1) \mathrm{C}(2-1) \mathrm{C}(0+1) \mathrm{H}$ & Reductive addition & $\mathrm{H} \Pi, \mathrm{H} \Pi$ \\
\hline $\mathrm{H} \rightarrow \mathrm{c} \Perp \mathrm{C}-\mathrm{C}-\mathrm{Z}$ & $\mathrm{H}(0+1) \mathrm{C}(2-1) \mathrm{C}(0+1) \mathrm{Z}$ & Isohypsic addition & \\
\hline $\mathrm{H}-\mathrm{C} \Perp \mathrm{C}=\mathrm{Z}$ & $\mathrm{H}(0-1) \mathrm{C}(2+1) \mathrm{C}(1-1) \mathrm{Z}$ & Isohypsic $\pi$-rearrangement (additive) & $\mathrm{H} \Pi, \mathrm{Z} \Pi$ \\
\hline $\mathrm{H}-\mathrm{C}=\mathrm{C}=\mathrm{Z}$ & $\mathrm{H}(0-1) \mathrm{C}(2-1) \mathrm{C}(2+1) \mathrm{Z}$ & Isohypsic $\pi$-rearrangement (additive) & \\
\hline$z-\theta-c \# c-$ & $Z(0+1) C(2-1) C(0+1) Z$ & Oxidative addition & \\
\hline$z-\theta-c \neq c=z$ & $\mathrm{Z}(0+1) \mathrm{C}(2-1) \mathrm{C}(1+1) \mathrm{Z}$ & Oxidative $\pi$-rearrangement (additive) & \\
\hline$z \rightarrow c \# c \triangleq z$ & $\mathrm{Z}(0+1) \mathrm{C}(2-1) \mathrm{C}(2+1) \mathrm{Z}$ & Ditto & \\
\hline $\mathrm{z} \theta \mathrm{c} \# \mathrm{c} \approx \mathrm{z}$ & $\mathrm{Z}(1+1) \mathrm{C}(2-1) \mathrm{C}(1+1) \mathrm{Z}$ & Ditto & $\mathrm{Z} \Pi, \mathrm{Z \Pi}$ \\
\hline $\mathrm{z}=\mathrm{c} \# \mathrm{c} \triangleq \mathrm{z}$ & $Z(1+1) C(2-1) C(2+1) Z$ & Ditto & \\
\hline $\mathrm{z} \equiv \mathrm{c} \Perp \mathrm{c} \triangleq \mathrm{z}$ & $\mathrm{Z}(2+1) \mathrm{C}(2-1) \mathrm{C}(2+1) \mathrm{Z}$ & Ditto & \\
\hline
\end{tabular}

を担っている。この理由から, 化合物に正準名をつける ためのアルゴリズムが数多く報告されている。この中で, 化合物を取り扱うシステムにおいては Morganによる方 法が現在標準的になっている ${ }^{24)}$ 。

ITS は拡張した構造式とみなせるから，これにも正準 名を付けることができる。筆者が提案した方法は, Morgan 法を拡張したものである ${ }^{15)}$ 。まず，ITS に含ま れる各節点を等価なグループに類別し, 優先順位をつけ る。この類別は, 新たに工夫した四種類の拡張結合度を 手掛りにして行う。優先順位の最高もののうち一つを選 んでNo.1の節点とする。No.2の節点は No.1の節点に 隣接する節点の中から, Morgan の方法に準じて選択す る。No.3 以降も同様にして番号を付してゆく。

このようにして得た番号 (候補の正準番号)に従って,
次のようなリストを作成する。

(a) 正準名の長さ

(b) 節点の数

(c) 環の数 (SSSR)

（d） 親リスト (FROM list)：i 番目の節点が隣接し ている上位の節点(親)の番号を並べたもの。

(e) 環結合リスト (RING CLOSURE list)：親リスト で記述されたもの以外の結合 (環結合)の両端点の 番号を並べたもの。

（f）恒結合リスト(PAR-BOND list)：(d) および (e )のリストの順に, 含まれる恒結合の数を並べ たもの。

（g）入結合リスト (IN-BOND list)：同様に入結合の 数を並べたもの。 
Table 5 Constructions and cleavages represented by Four-Nodal subgraphs ${ }^{5)}$.

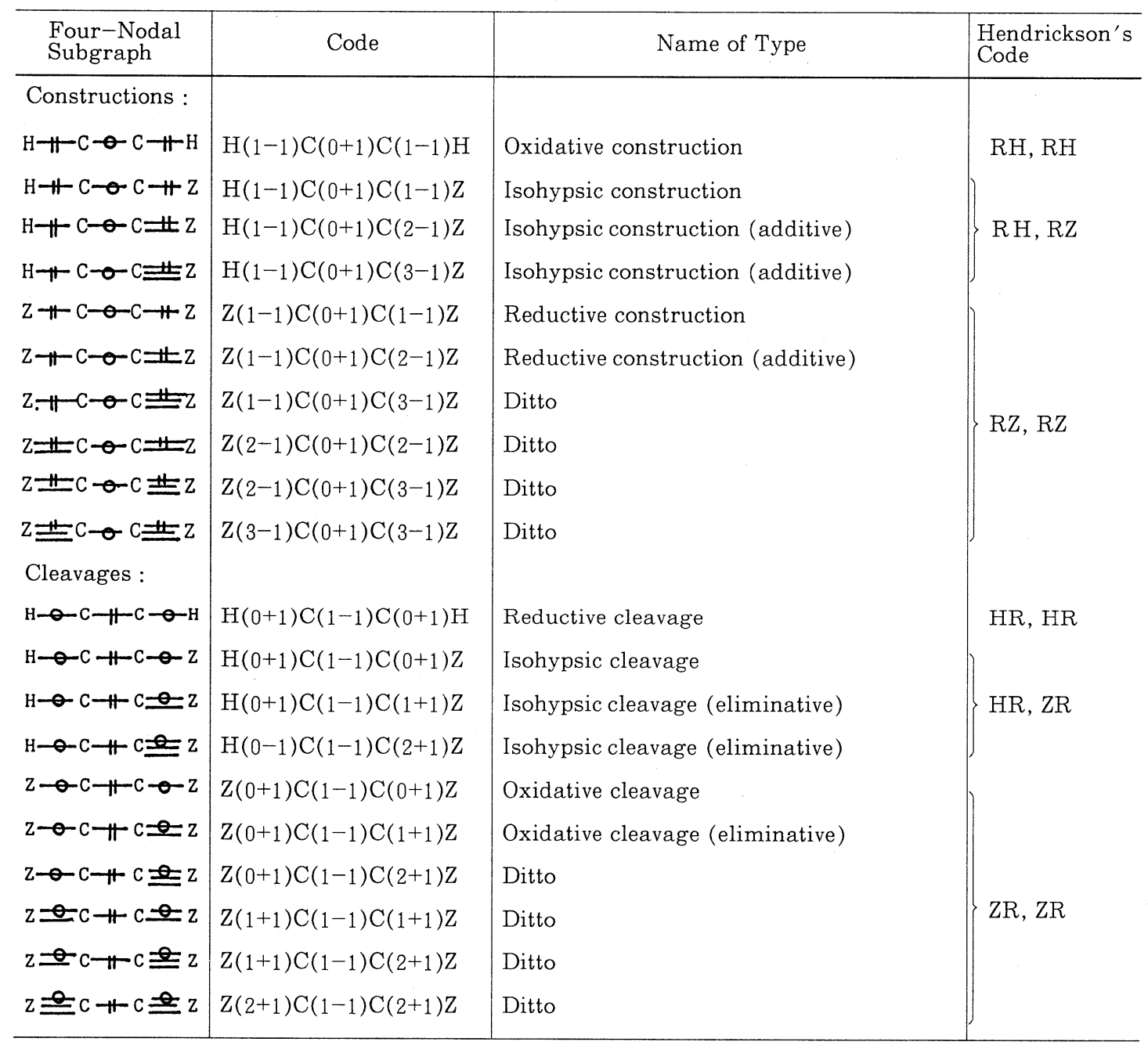

(h) 出結合リスト (OUT-BOND list)：同様に出結合 の数を並べたもの。

（i）原子リスト(ATOM list)：候補の正準番号の順 に原子番号を並べたもの。

（j）不変リスト(INTACT list) : 同様に, その節点 が反応中心であれば 0 ，なければ 1 を建てたもの。

(k) 出発系立体リスト (STARTING STEREO list)： 出発系の立体化学をパリティで表わして並べたも の。

（1）生成系立体リスト (PRODUCT STEREO list)： 同様に, 生成系の立体化学をパリティで表わして 並べたもの。

これらのリストを順に連結したものについて辞書的な
大小関係を比較して最小になるように可能な順列のすべ てにわたって繰返す。このようにして得たコードを正準 名とし，得られた番号を正準番号とする。例として，ス キーム 4 の ITS (18)の正準番号と正準名を図 8 に示し た。この例では, 各リストの間に斜線を入れて読み易く してあるが，圥長でないことを重要視する場合は除いて もよい。

ここでITS の正準名の意義について触れておきたい。 これまでの方法では反応式を基本としているため, 例え ば，スキーム 4 の反応は「 $\left[1,1^{\prime}\right.$ - dihydroxy-1, $1^{\prime}$ - dicyclopentyl から spiro [5.4] decan-2-one への塩酸触媒下の ピナコール転位」のように表現する。このように個別の 反応を表現するのに,「ピナコール転位」という反応型式 
Table 6 Types of reactions based on Three-Nodal subgraphs ${ }^{5)}$.

\begin{tabular}{|c|c|c|c|}
\hline $\begin{array}{l}\text { Three-Nodal } \\
\text { Subgraph }\end{array}$ & Code & Name of Type & $\begin{array}{l}\text { Hendrickson's } \\
\text { Code }\end{array}$ \\
\hline$H-O C-H$ & $\mathrm{H}(0+1) \mathrm{C}(1-1) \mathrm{H}$ & Proton exchange & $\mathrm{HH}$ \\
\hline$z \rightarrow c+z$ & $\mathrm{Z}(0+1) \mathrm{C}(1-1) \mathrm{Z}$ & Nucleophilic substitution & \\
\hline$z-0-c \pm z$ & $Z(0+1) C(2-1) Z$ & Nucleophilic addition to a double bond & \\
\hline$z=c+z$ & $Z(1+1) C(1-1) Z$ & Nucleophilic elimination to form a double bond & \\
\hline$z=c \pm z$ & $Z(1+1) C(2-1) Z$ & $\pi$-Rearrangement & 77 \\
\hline$z-\theta-c \pm z$ & $\mathrm{Z}(0+1) \mathrm{C}(3-1) \mathrm{Z}$ & Nucleophilic addition to a triple bond & $4 \Delta$ \\
\hline $\mathrm{z} \cong \mathrm{c}+\mathrm{z}$ & $Z(2+1) C(1-1) Z$ & Nucleophilic elimination to form a triple bond & \\
\hline $\mathrm{z}=\mathrm{C} \equiv \mathrm{z}$ & $Z(1+1) C(3-1) Z$ & $\pi$-Rearrangement & \\
\hline $\mathrm{z} \equiv \mathrm{E}=\mathrm{z}$ & $Z(2+1) C(2-1) Z$ & $\pi$-Rearrangement & \\
\hline $\mathrm{Z}-\mathrm{O}-\mathrm{C}-\mathrm{H}$ & $\mathrm{Z}(0-1) \mathrm{C}(1-1) \mathrm{H}$ & Oxidation & \\
\hline $\mathrm{Z}=\mathrm{C}-\|-\mathrm{H}$ & $\mathrm{Z}(1+1) \mathrm{C}(1-1) \mathrm{H}$ & Oxidative elimination to form a double bond & $\mathrm{ZH}$ \\
\hline $\mathrm{Z} \equiv \mathrm{C}-\mathrm{H}$ & $\mathrm{Z}(2+1) \mathrm{C}(1-1) \mathrm{H}$ & Oxidative elimination to form a triple bond & \\
\hline$H-O C-1-Z$ & $\mathrm{H}(0+1) \mathrm{C}(1-1) \mathrm{Z}$ & Reduction & \\
\hline $\mathrm{H}-\mathrm{O}-\mathrm{C} \# \mathrm{Z}$ & $\mathrm{H}(0+1) \mathrm{C}(2-1) \mathrm{H}$ & Reductive addition to a double bond & $\mathrm{HZ}$ \\
\hline$H-\sigma-C \equiv z$ & $\mathrm{H}(0+1) \mathrm{C}(3-1) \mathrm{H}$ & Reductive addition to a triple bond & \\
\hline
\end{tabular}

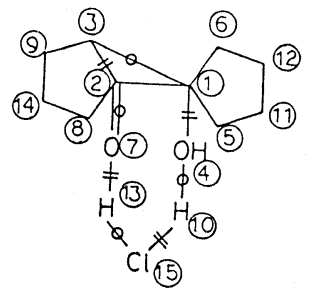

$0217 / 015 / 004 / 001001001001001002002003004005006007008010 / 0020$ $03009014011012013015 / 1001111110110100110 / 010001001000000001 / 0$ $01000000001011000 / 0606060806060806066010606016617 / 00001101101$

Fig. 8 The canonical numbering and code of the ITS $(18)^{15)}$.

と, 出発物および生成物の各称と, さらに触媒等の名称 を併記している。これが筆者のいう「構造十反応型式」パ ラダイムである1)。即ち, 個々の反応には, その反応自 体に名称があるのではなくて，上記のような術語の組み 合せがあるにすぎないのである。このことは，出発物お よび生成物を結合表の形で表現しても同じである。

ところがスキーム 4 の反応を ITS (18)で表わすと, 図 8 のような正準名を付けることができるのである。これ
は数字の列ではあるが，立派な名称である。かくして， 個々の反応に名称を付すことが可能になった。（もちろ んITS (18)を構造式とみなして, 化合物における IUPAC 命名法のごとき規約を工夫すれば，自然語の名 称を付けることも可能である。しかし，コンピュータ利 用の立場からは上記の数字列の正準名で十分である。）本 項で述べた正準名は個々の反応に一元的な名称をつけた 初めての例ということになる。このように, ITS の正準 名の意義は見掛以上に深いものがある。

ここでは, Morgan 法の拡張のみを述べた。しかしな がら，化合物における他の正準名付与プログラムのいず れも，拡張すればITS の正準化に使えることを指摘し ておく。基本的に重要なことは, 反応に正準名をつける というアイデアが, ITS を構造式 (図形あるいはグラフ) とみなしたことに由来している事実である。

\section{7. 部分グラフの正準名 ${ }^{16)}$}

上記第 3,4 , および 5 項で各種の部分グラフが反応型 式(タイプ)の記述子として有効なことを述べた。これら の議論では，グラフ的(図形的)な表現を主に用いた。コ ンピュータで取り扱うためには，これらの部分グラフを 
コード化する必要がある。上記の議論の範囲では，CBN を用いるコード化が有効である。その例は，表 4 6に 示した通りである ${ }^{5}$ 。環状一本緒反応の反応中心グラフ のコード化については原報2゙に記載した。明らかなよう にこのコード化は二本緒以上の反応中心グラフ(あるい は他の部分グラフ)には適用できない。

部分グラフといえども, ITS と同じく構造式であるか ら, 第 6 項の方法と同様に正準名を付すことができる ${ }^{16)}$ 。 この方法によるコード化は，一本緒反応に限らず二本緒 以上の場合でも適用できることに特長がある。部分グラ フでは，上記リストのうち(a)〜（i ）までを記述する。 図 9 に代表的な反応型式 (タイプ) 4 種の正準名を示し た。これらの反応中心グラフは, (f)〜 ( h ) のリスト (図 中下線の部分)の相異で区別される。

このように，ITS から抽出したどのような部分グラフ (部分構造)でもコード化することができる。従ってどの ような反応タイプでも，名称(正準名)を付すことができ るようになった。

ここで, 化合物と反応とを比較して, ITS 法の特徴を 明らかにしたい。表 7 に示すように，化合物の分野では， 構造 (あるいは構造式)に対応するコンピュー夕内部表現 として結合表および正準名が使われる。化合物は，その 部分構造によって化合物タイプに(多くは官能基によっ てケトンとかアルコールとかに)類別される。コンピュー 夕は取り出した部分構造 (多くは官能基)をフラグメント コードとして取り扱う。ところが反応の分野では，これ までは, 反応や反応型式 (タイプ) という概念はあっても, その表現は化合物の構造式を流用していたにすぎない （反応の前後の構造式を矢印で連結したいわゆる反応 式)。ITS 法で導入した構造式としてのITS およびその 各種部分グラフ(部分構造) は, 表 7 に示すように, 化合 物における構造式と部分構造に対応している。コン ピュー夕内部表現としては, 前項および本項で述べた正 準名あるいは結合表が使用できる。ITS を構造式とみな す取り扱いによって, 表 7 に示すような見事な対応関係 が生まれる。反応タイプを，ITS の部分構造として認識 し，しかもそれに正準名を付すという取り扱いは，従来
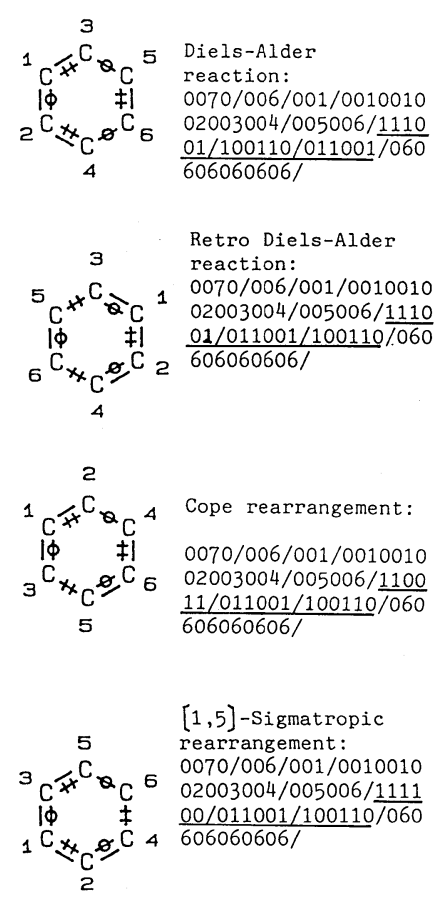

Fig. 9 Canonical codes for RCGs.

の方法に比較して質的に異なっているといえよう。

\section{8. 形式電荷の処理 $\left.{ }^{9}, 20\right)$}

第 1 7 項の議論では, 形式電荷 (formal charge) およ び配位結合 (coordinate bond) に関わる問題は触れないで おいた。実は, この問題の解決策として, 化合物の構造 に限っても決定版があるわけではない25)。例えば，ジメ チルスルホキシドは, Lewis 構造の記法の他に, $\left(\mathrm{CH}_{3}\right)_{2}$ $\mathrm{S}=\mathrm{O}(\mathrm{A}), \quad\left(\mathrm{CH}_{3}\right)_{2} \mathrm{~S} \oplus-\mathrm{O} \Theta(\mathrm{B}),\left(\mathrm{CH}_{3}\right)_{2} \mathrm{~S} \rightarrow \mathrm{O}(\mathrm{C})$ など様々 に表現されている。スルホキシドが反応に関与する場合, 電子対の移動で考えることが多いので, 通常はAまたは B の記法が用いられる。それにしても，コンピュータで 取り扱う場合は記号を統合する必要がある。A,B のう ちどちらを採用するか?あるいは A と B を両方採用し て，両者の変換プログラムを作成するか? それとも新し

Table 7 Comparison between the representation of compounds and that of reactions.

\begin{tabular}{l|l|l|l}
\hline \multicolumn{1}{c|}{ object } & \multicolumn{1}{|c}{ concept } & \multicolumn{2}{c}{ representations for a computer } \\
\hline $\begin{array}{l}\text { compound } \\
\text { compound type }\end{array}$ & $\begin{array}{l}\text { structure } \\
\text { substructure }\end{array}$ & $\begin{array}{l}\text { connection table } \\
\text { fragment code }\end{array}$ & canonical name \\
\hline $\begin{array}{l}\text { reaction } \\
\text { reaction type }\end{array}$ & ITS & $\begin{array}{l}\text { ITS connection table } \\
\text { (code) }\end{array}$ & $\begin{array}{l}\text { canonical name } \\
\text { canonical name }\end{array}$ \\
\hline
\end{tabular}


い記法を案出するか？

共有結合とイオン結合との境界は連続的である。例え ば，塩化水素は目的によって $\mathrm{H}-\mathrm{Cl}$ とも $\mathrm{H} \oplus \mathrm{Cl} \Theta$ とも書け る。それでは，塩化アン白ニウムの場合はどうであろう か。化学者は通常 $\mathrm{H}_{4} \mathrm{~N} \oplus \mathrm{Cl} \ominus$ と書いて $\mathrm{H}_{4} \mathrm{~N}-\mathrm{Cl}$ とは書か ない(もっとも $\mathrm{NH}_{4} \mathrm{Cl}$ あるいは $\mathrm{NH}_{3} \cdot \mathrm{HCl}$ などの省略記号 は許される)。ここには結合論に関する化学者の歴史的 な思い入れが込められている。しかしコンピュータで取 り扱う場合は(記号として処理する立場からは), 前のパ ラグラフと同じ困難にぶつかる。

ITS 法では, 合成空間 (synthesis space) と電荷空間 (charge space)を考えて, 上記の問題を処理する9)。ス キーム 6 に示したスルホンアミドの生成反応を例にと る ${ }^{15)}$ 。この反応に対応する完全 ITS (full ITS) として 29 を考える(図 10)。この完全ITS は, ピリジニウムクロ リドの生成を記述するために電荷空間をもっている。電 荷空間は, 関与する電荷を含む注7)。一方, 原子は合成 空間に含まれる。電荷および原子を節点とみて, これら を, 恒結合, 出結合, 入結合でつなぐ。この際, 両空間 にまたがる結合 (interspace bond, 空間間結合) は対応 する電荷間の結合と同一種の虚結合としておく。

通常のITS (30) を得るには，ITSへの投影(Projection to ITS, 略称 $\left.\mathrm{P}_{\mathrm{its}}\right)$ を考える。これは, 電荷の節点を取り 除き,さらに空間間結合を除去し, 電荷間の結合 (intraspace bond 空間間結合) を対応する原子の節点間 に投影する操作である。 $\mathrm{P}_{\mathrm{its}}$ により得られた ITS (30)を さらにPP 操作にかけると五価の窒素を含んだ表現 (32) が生ずる。完全 ITS の PP 操作では, 電荷空間を含んだ 表現 (33)が生ずる。ITS 法では, 表現 32 を表現 33 の投 影として許容することにする。

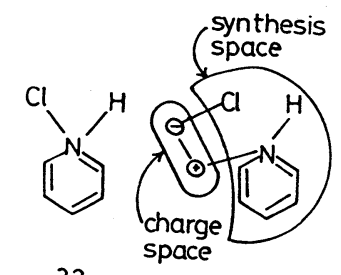

33

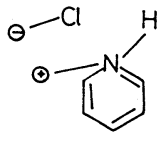

34
一方, 電荷間の結合を除去する操作(イオン型 ITS へ の投影, projection to ionic ITS, 略称 $\left.\mathrm{P}_{\text {ion }}\right)$ によれば, 29 から,イオン型 ITS (31) が生ずる。31 の PS および PP からは, ピリジニウムイオンの通常の表現 (34)を含

注 7）スルホンアミドの部分も電荷空間によって表現することもできる が,ここでは省略した。

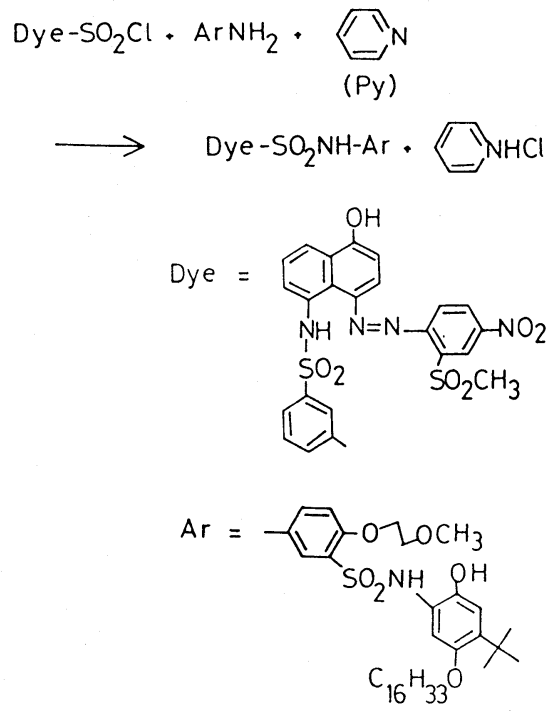

Scheme $6^{15)}$
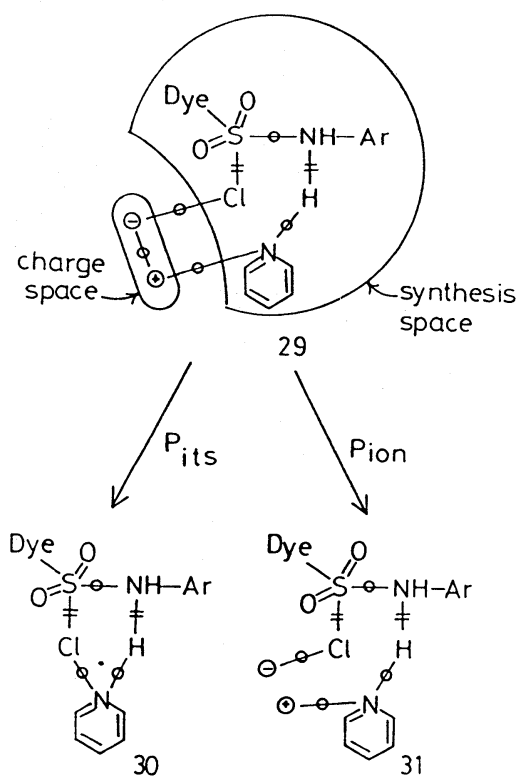

Fig. 10.

んだ反応式が得られる。

以上のような約束のもとに, 30 のような通常のITS を前記第 1〜7 項で示した方法で取り扱うことにする。 ITS (30)は五価の窒素を生ずるという意味で, 化学的に は退歩にみえるかも知れないが, 大部分の反応情報はこ 
の式で説明できる。これで説明できない情報は完全 ITS

で補うことにするわけである。

コンピュータの側からいえば, 完全 ITS のみを格納 しておけばよい。あとの表現は, $\mathrm{P}_{\text {its }}, \mathrm{P}_{\text {ion }}, \mathrm{PP}, \mathrm{PS}$ な どの操作で発生させることができる。完全 ITS の格納 は，CBNを用いた結合表による。

\section{9. 反応型式の列挙(数え上げ $)^{3,4,7,8,18,20)}$}

第 3 項で反応中心グラフ $(\mathrm{RCG})$ が反応型式の記述子と なることを述べた。本項では, RCG の組織的な列挙法 について論ずる。 RCG の列挙は，反応データベースを 作る場合の規模の見積りにとって重要である。また，反 応設計にとっても, 可能性のある反応型式を網羅すると いう意味で必須である。

容易にわかるように, 反応の列挙は図 2 に示した経路 の逆を辿ればよい。図 11 にこの戦略による RCG の列挙 法を示した。まず基本反応グラフ $(\mathrm{BRG})$ を考え，この辺 に単恒結合 (一) あるいは二重恒結合 $(=)$ が置換すると考 える。かくして得られた反応グラフ $(\mathrm{RG})$ の各頂点(節点) に原子が置換して，RCG が生ずるとする。この列挙は コンピュータでしらみつぶしに行うことも可能である

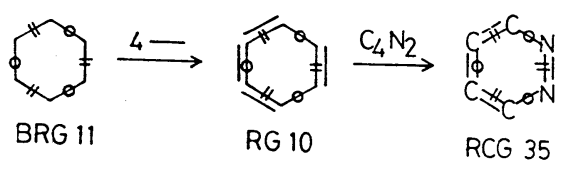

Fig. 11 Enumeration of RGs and RCGs.

が，ここではもうすこしスマートに数学的に取り扱うこ とにしょう。

まず RG の列挙を六角形の BRG (11)を例にとって考 えよう。この BRGに 4 本の単恒結合 (一)を置換させる 仕方には 4 種類ある (図 9)。これらを RG 異性体 (RG isomers) と呼ぶことにする。この場合に 4 個の RG 異性 体しか存在しないことなどを示すのが目的である。

BRG (11)の各辺は $\mathrm{D}_{3}$ と同型な置換群に属する3)。 Pólya の定理によれば，その巡回指標 (cycle index) は次 の式で表わされる注8)。

$$
Z\left(D_{3}\right)=(1 / 6)\left(s_{1}^{6}+3 s_{1}^{2} s_{2}^{2}+2 s_{3}^{2}\right)
$$

この式の右辺の変数 $\mathrm{s}_{\mathbf{k}}$ に，次のような結合図形目録 (bond-figure inventory) を代入する。

$$
\mathrm{s}_{\mathrm{k}}=1+\mathrm{x}^{\mathrm{k}}+\mathrm{y}^{\mathrm{k}}
$$

ここに, $\mathrm{x}$ は単恒結合 $($ 一) の, $\mathrm{y}$ は二重恒結合 $(=)$ の置

\begin{tabular}{|c|c|c|c|c|}
\hline $\mathrm{m}$ & $\mathrm{n}$ & $\begin{array}{l}\text { Nos. of reacn } \\
\text { graphs }\end{array}$ & $\begin{array}{l}\text { Nos. of reacn } \\
\text { pairs }^{c}\end{array}$ & Reaction graphs ${ }^{a, d}$ \\
\hline 0 & 0 & 1 & 1 & \\
\hline 1 & 0 & 2 & 1 & \\
\hline 2 & 0 & 4 & 3 & \\
\hline 3 & 0 & 6 & 3 & \\
\hline 4 & 0 & 4 & 3 & 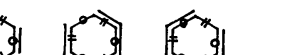 \\
\hline 5 & 0 & 2 & 1 & \\
\hline 6 & 0 & 1 & 1 & \\
\hline
\end{tabular}

Table 8 The reaction graphs of hexagonal class $(m=0 \sim 6, n=0)^{1,3)}$.

a Table 8 may contain several reaction graphs which are not reasonable chemically. But they are not omitted for completeness of the list. ${ }^{b}$ The numbers of reaction graphs are the coefficients of $x^{m} y^{n}$ in $G(x, y)$, ${ }^{c}$ The numbers of reaction pairs are the coefficients of $x^{m} y^{n}$ in $R G$-pair-counting polynomial $P(x, y)$, ${ }^{d}$ Each-couple of reaction graphs linked with a bracket is a reaction pair. 
換に対応している。得られた式を展開すると，次に示す ような母関数 (generating function) $\mathrm{G}(\mathrm{x}, \mathrm{y})$ が生ずる。

$$
\begin{aligned}
G(x, y)= & Z\left(D_{3}, 1+x^{k}+y^{k}\right) \\
= & 1+2 x+2 y+4 x^{2}+6 x y+4 y^{2}+6 x^{3}+12 x^{2} y \\
& +12 x^{2}+6 y^{3}+4 x^{4}+12 x^{3} y+18 x^{2} y^{2} \\
& +12 x^{3}+4 y^{4}+2 x^{5}+6 x^{4} y+12 x^{3} y^{2}+12 x^{2} y^{3} \\
& +6 x^{4}+2 y^{5}+x^{6}+2 x^{5} y+4 x^{4} y^{2}+6 x^{3} y^{3} \\
& +4 x^{2} y^{4}+2 x^{5}+y^{6}
\end{aligned}
$$

ここで $\mathrm{x}^{\mathrm{m}} \mathrm{y}^{\mathrm{n}}$ の係数は, $\mathrm{m}$ 個の単恒結合 (一) と $\mathrm{n}$ 個の二 重恒結合 $(=)$ をもつ RG 異性体の数を表わす。このよう な $\mathrm{G}(\mathrm{x}, \mathrm{y})$ を $\mathrm{RG}$ 数え上げ多項式 (RG-counting polynomial) と呼ぶことにする。表 8 に $\mathrm{m}=0 \sim 6, \mathrm{n}=0$ の場合を例示する。

表 8 中, 大カッコで結んだ 2 個の RG は互いに逆反応 の関係にある。このような一対の RG を反応対 (reaction pair) と呼ぶ。また, 表中単独のものは, 反応対が自己 に一致するもので, 自己反応対 (self-reaction pair) と 呼ぶ。原報引には，反応対を数え上げる多項式 (RG-pair-counting polynomial)も誘導されている注9)。

同様の取り扱いで, 偶数員環の $R^{3}{ }^{3}$, 奇数員環の $\left.R G^{4}\right)$ および各種多本緒の $\mathrm{RG}^{7,8)}$ の数え上げを行った。詳しく は原報を参照されたい。

次に, 与えられた RG から RCG 異性体 (RCG isomers) を数え上げる方法について述べる ${ }^{18,20)}$ 。 RG (10) を例にとる。この反応グラフは $\mathrm{C}_{2}$ に同型な置換群に属 する。図 12 に示すように各項点は三種類の節点をもっ ている。これを置換群の言葉では,「軌道 (orbit)として, $\Delta_{1}=\{1,2\}, \Delta_{2}=\{3,4\}, \Delta_{3}=\{5,6\}$ をもつ」という注10)。

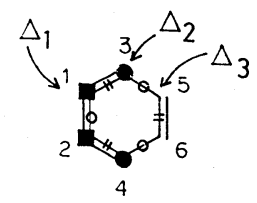

Fig. 12 Orbits of RG 10.

このうち， $\Delta_{1}$ の各頂点は，三価以上の原子しか置換し 得ないのに対して, $\Delta_{2}$ および $\Delta_{3}$ の各頂点は, 二価以上 の原子であれば置換しうる。このように各頂点に置換し うる原子の最小の原子価を最小原子価 (obligatory minimum valency) と称することにしょう。この定式化によ

注 8) グラフ理論では, 通常頂点のみの置換を考える。本稿の取り扱いは, 辺への置換を考えている点で新しい。

注 9）従来の取り扱いには, 反応対の概念がない。本稿の反応対および 自己反応対の定義により，反応型式が明確に取り扱えるようになった。 注 10）量子化学でいう orbital とは異なることに注意。
り RCG の数え上げは，最小原子価を考虑に入れなけれ ばならないことがわかる。 $\Delta_{1} に \mathrm{a}_{\mathrm{k}}$ なる変数， $\Delta_{2}$ およ び $\Delta_{3}$ に $\mathrm{b}_{\mathrm{k}}$ なる変数を与えることにすれば，（拡張され た) Pólya の定理は，次のような巡回指標を与える(証明 は原報18)参照)。

$$
Z\left(\mathrm{C}_{2}\right)=(1 / 2)\left(\mathrm{a}_{1}^{2} \mathrm{~b}_{1}^{4}+\mathrm{a}_{2} \mathrm{~b}_{2}^{2}\right)
$$

ここで簡単のため, 置換させる原子を $\mathrm{C}, \mathrm{N}, \mathrm{O}$ の中 から選ぶことにする。この場合， $\Delta_{2}$ 抢よび $\Delta_{3}$ の各頂点 は，C， N，Oの寸べてが置換しうるのに対し， $\Delta_{1}$ の頂 点に置換するのは $\mathrm{C}, \mathrm{N}$ のみである。従って，次のよう な原子図形目録 (atom-figure inventory)を導入する。

$$
\left\{\begin{array}{l}
a_{k}=1+u^{k} \quad\left(\Delta_{1} \text { に対して }\right) \\
b_{k}=1+u^{k}+v^{k} \quad\left(\Delta_{2} \text { および } \Delta_{3} \text { に対して }\right)
\end{array}\right.
$$

ここで $\mathrm{u}$ は $\mathrm{N}, \mathrm{v}$ は $\mathrm{O}$ の置換に対応している。これらを 巡回指標に代入して, RCG 数え上げ多項式 $\mathrm{G}(\mathrm{u}, \mathrm{v})$ を得 る。

$$
\begin{aligned}
G(u, v)= & 1+3 u+2 v+9 u^{2}+10 u v+4 v^{2}+10 u^{3}+20 u^{2} v \\
& +12 u v^{2}+2 v^{3}+9 u^{4}+20 u^{3} v+20 u^{2} v^{2}+6 u v^{3} \\
& +v^{4}+3 u^{5}+10 u^{4} v+12 u^{3} v^{2}+6 u^{2} v^{3}+u v^{4}+u^{6} \\
& +2 u^{5} v+4 u^{4} v^{2}+2 u^{3} v^{3}+u^{2} v^{4}
\end{aligned}
$$

この多項式の $\mathrm{u}^{\mathrm{m}} \mathrm{v}^{\mathrm{n}}$ の係数が, $\mathrm{C}_{6-\mathrm{m}-\mathrm{n}} \mathrm{N}_{\mathrm{m}} \mathrm{O}_{\mathrm{n}}$ の RCG 異性 体の数を表わしている。表 9 に, $\mathrm{C}_{4} \mathrm{NO}$ (10 個) および $\mathrm{C}_{4} \mathrm{~N}_{2}$ (9 個)の RCG 異性体を例示した。これらの個数は, $\mathrm{G}(\mathrm{u}, \mathrm{v})$ 中 uv および $\mathrm{u}^{2}$ の係数として表われている。原 報18)には, 各種の RG をもとにした RCG の数え上げ多 項式を示した。

Table $9 \quad \mathrm{C}_{4} \mathrm{NO}$ and $\mathrm{C}_{4} \mathrm{~N}_{2}$ isomers based on $\mathrm{RG}(10)^{18)}$

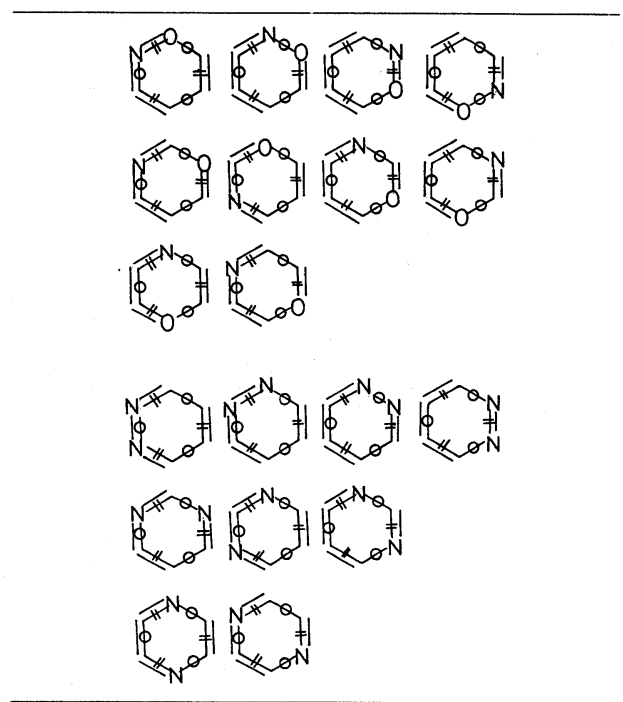




\section{0. おわりに}

既に, 表 7 の説明として, 反応における概念と化合物 における概念との対応を述べた。この対応は反応をITS で表わすことによってはじめて明確な形として露呈した ものである。表 10 は，この対応関係をさらに補足した ものである。有機化合物は, 前後で変化しない反応であ るとみなせば，反応に包含される。このことは，「ITS のうちで, 恒結合のみで構成されているものが, 有機構 造である」ということに言い直せる。即ち ITS は, 通常 の有機構造を包含する。虚結合は, 通常の結合の拡張で あり後者を含むこと等々, 表 10 に示す包含関係は重要 である。

Table 10 Extended concepts in ITS ${ }^{13)}$.

\begin{tabular}{ll}
\hline Organic reaction & $\supset$ Organic compound \\
ITS & $\supset$ Structure \\
ITS connection table & $\supset$ Connection table \\
Imaginary bond & $\supset$ Bond \\
$\begin{array}{l}\text { Complex bond } \\
\text { number }\end{array}$ & $\supset$ Bond multiplicity \\
ITS ring & $\supset$ Ring \\
\hline
\end{tabular}

この事実は，これまで化合物の分野で開発されたコン ピュータ技術(ソフトウェア)が，ある拡張を加えれば ITS 法の中に取り込めることを示唆する。それ以上に, 化合物構造の範囲では見通しがはっきりしないようなも のでも，ITS の範囲に拡張して考えるとより広い展望が 開けることは特筆すべきであろう(例えばESER など)。

このようにして，有機反応を記述する新しい言葉とし て，ITS とそれに関係する諸概念が得られた。ITSを基 本にしたコンピュータシステムFORTUNITS (Fuji Organic Reaction Treating UNity based on Imaginary Transition Structures)を現在開発中であることを申し添える。

\section{謝 辞}

カラーロ絵は, FORTUNITS 登録システム(プロトタイ プにより描画したものである。プロトタイプの作製, 作 画および撮影の労をとられた当研究所研究員竹内雅志氏
に深謝する。

(昭和 63 年 11 月 14 日受理)

\section{文献}

1）藤田眞作, 有合化, 44, 354 (1986)

2) S. Fujita, J. Chem. Inf. Comput. Sci., 26, 205 (1986)

3) Idem, ibid ., 26, 212 (1986)

4) Idem, ibid ., 26, 224 (1986)

5) Idem, ibid ., 26, 231 (1986)

6) Idem, ibid ., 26, 238 (1986)

7) Idem, ibid., 27, 99 (1987)

8) Idem, ibid., 27, 104 (1987)

9) Idem, ibid ., 27, 111 (1987)

10) Idem, ibid., 27, 115 (1987)

11) Idem, ibid., 27, 120 (1987)

12) S. Fujita, J. Chem. Soc. Perkin II ., 597 (1988)

13) S. Fujita, J. Chem. Inf. Comput. Sci., 28, 1 (1988)

14) Idem, ibid ., 28, 78 (1988)

15) Idem, ibid ., 28, 128 (1988)

16) Idem, ibid ., 28, 137 (1988)

17) S. Fujita, Pure Appl. Chem ., 61, 605 (1989)

18) S. Fujita, Bull. Chem. Soc. Japan, 61, 4189 (1988)

19) J. Haggin, Chem. Eng. News, 64, 75 (1986)

20a) S. Fujita, Bull. Chem. Soc. Japan, 62, 662 (1989)

b) S. Fujita, J. Chem. Inf. Comput. Sci., 29, 22 (1989)

21) M. Plotkin, J. Chem. Doc., 11, 60 1971)

22a) E.J. Corey, G. Petersson, J. Am. Chem. Soc., 94, 460 (1972)

b) W.T. Wipke, T.M. Dyott, J. Chem. Inf. Comput. Sci., 15, 140 (1975)

23) J.B. Hendrickson, J. Am. Chem. Soc., 93, 6847 (1971)

24) H.L. Morgan, J. Chem. Doc., 5, 107 (1965)

25) W. Hückel, "Theoretische Grundlagen der Organischen Chemie", 第 8 版 (訳：ヒュッケル有機化 学) 商工出版社第 1 巻, 第 1 部, 第 1 章 (1959)

(参考書)

26）小野修一郎編, コンピュータケミストリー, 丸善 (1988)。特に第 3 章 (工藤喜弘) および第 4 章 (花井 荘輔) 


\section{用語解説}

構造式としての虚遷移構造(式)を正確に記述するために，本稿では多くの術語を導入した。このほとんどが筆者によ る新造語である。これらの術語が定着することを希って，辞書形式での解説を試みる。

アイティーエス ITS imaginary transition structure (虚遷移構造)の略。

アイティーエスかん ITS 環 $\rightarrow$ よかん

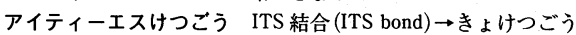

アイティーエスけつごうひょう ITS 合表かきょせんいこうぞうのけつごう ひょう

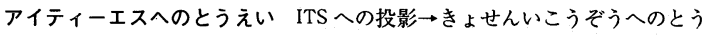
えい

イーエスイーァール ESER essential set of essential rings の略。虚環から, 反応情報として必要のない環構造(結束環, 多重結束環および従属環)を除い た残りの環の集合。

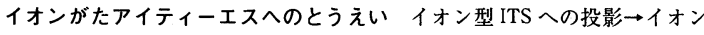
がたきょせんいこうぞうへのとうえい

イオンがたきょせんいこうぞう イオン型虚遷移構造 (ionic imaginary transition structure) 反応に電荷が関与することを示すために, 電荷を独立の節 点として明示した虚遷移構造。通常は使用せず，表示用にのみ用いる。 イオンがたきょせんいこうぞうへのとうえい イオン型虚遷移構造への投影 (projection to ionic imaginary transition structure) 完全虚遷移構造から，1 オン型虚遷移構造を作る操作。

いっぽんしょはんのう一本緒反応 (one-string reaction) 反応緒を一本のみ 含む虚遷移構造で表わされる反応。

かいかんきょう 開環橋 (bridge of ring-opening) 虚遷移構造に含まれる環構 造の一つ。開環反応に対応する。

かんぜんきょせいこうぞう 完全虚遷移構造 (full imaginary transition structure) 電荷を含む反応を記述するために，電荷を節点として含む電荷空 間を考え,これを原子を含む合成空間に付属させた虚遷移構造。電荷内での 虚結合を空間内結合, 電荷空間と合成空間の間を結ぶ虚結合を空間間結合と いう。

きほんはんのうグラフ 基本反応グラフ (basic reaction graph)反応グラフか ら恒結合を除いたグラフ。正味の電子対の動きを示す。基本反応グラフは, 反応緒を一本以上含んでいてもよい。

きゃくはんのうへのへんかん 逆反応への変換 (transformation to the reverse reaction) 虚遷移構造およびその部分構造において, すべての入結合を 出結合に，すべての出結合を入結合に変える操作。生じた構造は，もとの反 応の逆反応を表わす。

きょかん＼cjkstart虚環 (imaginary ring)虚㟟移構造に含まれる環。開環橋, 閉環橋, 転位橋, 不変環およびその他の環に分類される。虚環の節点のすべてが一本 の反応緒の節点と一致する場合もある。ITS 環ともいう。

きょけつごう 虚結合 (imaginary bond) 恒結合, 入結合, 出結合の組み合せ からなる結合。ただし入結合と出結合は同時に含まれることはない。15 種 類の虚結合が存在する。コンピュー夕の内部表現として複素結合数に対応さ せて用いる。

きょせんいこうぞう 虚遷移構造 (imaginary transition structure)ITS と略す こともある。反応に関与する原子または原子団(節点)を, 恒結合, 入結合お よび出結合で結んだ構造。二つの節点の間の結合は, 恒結合のみ, 恒結合と 入結合の組み合せ, 恒結合と出結合の組み合せのいずれかである。これらの 組み合せを虚結合と称する。

きょせんいこうぞうのけつごうひょう 虚遷移構造の結合表 (connection table of imaginary transition structure) 虚遷移構造に含まれる原子または原 子団のリストとそれらを結ぶ虚結合を複素結合数で表わしたリストとを含む 表。ITS のコンピュータ内部表現の一つ。他の情報(例えば原子等の節点の $x y z$ 座標值など)を付属させてもよい。

きょせんいこうぞうへのとうえい 虚遷移構造への投影 (projection to imaginary transition structure) ITS への投影ともいう。完全虚遷移構造から電 荷空間を取除いて，虚遷移構造を作る操作。

くうかんかんけつごう 空間間結合 (interspace bond)合成空間と電荷空間と を結ぶ虚結合。

くうかんないけつごう＼cjkstart空間内結合 (intraspace bond)合成空間内または電荷
空間内に含まれる虚結合。

けつごうひょう 結合表

ごうせいくうかん 合成空間 (synthesis space) 完全虚遷移構造において, 原 子および原子団を節点として含みそれらの間の虚結合を含むような空間。 さんせつぶぶんグラフ 三節部分グラフ (three-nodal subgraph) 炭素反応中 心に 2 個の非炭素反応中心が結合したグラフ。二本の虚結合のうち，片方は 入結合を含み，他方は出結合を含む。各種の置換反応の記述子となる。 じこはんのうつい 自己反応対 (self-reaction pair) 逆反応への変換によって 不変な反応対。

しゅつけつごう 出結合 (out-bond) 虚遷移構造の中に存在する結合の一つ。 出発系のみに由来する結合である。グラフ的に，ーで表わす(カラー表示 では，例えば赤の直線を用いる)。

しゅっぱつけいへのとうえい 出発系への投影 (projection to the starting stage），虚遷移構造またはその部分グラフより，入結合を消去する操作。こ の操作により, 出発系が再生される。PS と略す。

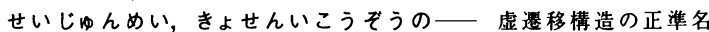
(canonical name of an imaginary transition structure) 虚遷移構造の各節点 に一義的な番号を付し，それに従って一義的に作成したコード。

せいじゅんい,ふふふんグラフの一一 部分グラフの正準名 (canonical name of a subgraph) 虚遷移構造の部分グラフを取り出し, この各節点に一義 的な番号を付しこれをもとに作成した一義的なコード。反応型式に対応す る部分グラフに付した正準名は，反応の分類に有効である。

せいせいけいへのとうえい生成系への投影 (projection to the product stage）虚遷移構造またはその部分グラフより，出結合を消去する操作。こ の操作により, 生成系が再生される。PP と略す。

タイプエイけつごう タイプA 結合 (type A bond) 虚結合のうち，恒結合を

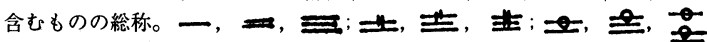
の 9 種。

タイプシーけつごう タイプC 結合 (type C bond) 虚結合のうち, 入結合の みからなるものの総称。, も, およびもの司 3 種。

タイプビーけつごう タイプ B 結合 (type B bond) 虚結合のうち, 出結合の みからなるものの総称。ー，\#および \#の 3 種。

たんこうけつごう 単恒結合 (single par-bond) 虚結合 (\#, ニ゚など)に 含まれる一重の恒結合。例えば，一は，出結合に単恒結合を付加したも のとみなせる。

てんいきょう 転位橋 (bridge of rearrangement) 虚逻移構造に含まれる環構 造の一つ。出結合のみからなる虚結合 (タイプ B 結合) 1 本と, 入結合のみか らなる虚結合 (タイプC結合)を含み，他の虚結合は夕イプA結合である(す べて恒結合を含む)ような環をいう。この環の存在は, 転位反応であること を示す。

でんかくうかん：電荷空間 (charge space) 反応に関与する電荷を節点とみな しこれを含む空間を仮想的に考える。この空間を電荷空間という。電荷は, 空間内結合あるいは空間間結合で結ばれる。

にじゅうこうけつごう 二重恒結合(double par-bond)虚結合（き，きな ど)に含まれる二重の恒結合 $(=)$ 。

にほんしょはんのう 二本緒反応 (two-string reaction) 反応楮を 2 本含む虚 遷移構造により表わされる反応。

にゅうけつごう 入結合 (in-bond) 虚遷移構造の中に存在する結合の一つ。 生成系のみに由来する結合である。記号としてーのー(カラーでは緑の直線) を本稿では用いる。結合が生成することに相当する静的表現。

はんのうかく 反応核 (reaction kernel) 炭素反応中心が椱数連っているグラ フ。炭素中心 1 個のみの場合も含む。

はんのうグラフ 反応グラフ (reaction graph) 虚遷移構造より反応中心とそ れらの間の虚結合を取出したグラフ。ただし，反応中心を抽象的に球とみな す。

はんのうしょ 反応緒 (reaction string)出結合および入結合が交互に連った 図形。虚逻移構造および部分グラフのいずれに現われてもよい。有機電子論 
における電子の移動を抽象化したものといえる。

はんのうしょすう 反応緒数 (stringity) 虚遷移構造などに含まれる反応緒の 数。一本緒反応, 二本緒反応の項をみよ。

はんのうちゅうしん 反応中心(reaction center)出結合および(または)入結 合が接合している節点。

はんのうちゅうしんグラフ 反応中心グラフ(reaction-center graph)虚遷移 構造に含まれるすべての反応中心とそれらの間の虚結合を取出した部分グラ フ。反応型式を表わす。反応中心の節点の値(原子の種類)を不問としたもの が反応グラフである。

はんのうつい 反応対 (reaction pair) 逆反応への変換操作により相互に変化 する一対の反応中心グラフ(または反応グラフ)。自己反応対の項も参照。 ふくそけつごうすう 複素結合数 (complex bond number) 虚結合の内部表現 として定めた一対の整数 $(a \quad b)$ 。ただし $a$ は出発系での多重度, $b$ は生成 系と出発系の多重度の差を表わす。定義により $a+b$ は生成系の多重度を表 わす。
ふへんかん 不変環 (invariant ring) 虚遷移構造に現われる環構造の一つ。 環に含まれる虚結合のいずれもが，少なくとも 1 本の恒結合を含むような場 合をいう。

へいかんきょう 閉環橋 (bridge of ring closure) 虚遷移構造に含まれる環構 造の一つ。入結合のみからなる虚結合 (タイプC 結合)を一本以上含み, 残り の虚結合はタイプA結合である(すべて恒結合を含む)ような環。閉環反応に 対応する。

まったんきじゅつし 末端記述子 (terminal descripter)三節または四節部分 グラフ(一般に $\mathrm{n}$ 節部分グラフ)の末端にある非炭素反応中心を取り出しそ れらに虚結合を接合させた部分グラフ。残りの炭素反応中心よりなる部分グ ラフを反応核という。

よんせつふぶんグラフ 四節部分グラフ (four-nodal subgraph) 相瞵る 2 個の 炭素反応中心とそれらに接合した非炭素反応中心を取り出したのち, 各節点 を結ぶ虚結合を付した部分グラフ。脱離反応，付加反応などの反応型式を表 わす。

\section{次号予 定}

「ホストーゲストケミストリー」特集号

巻 頭 言

分子認識化学の幕開け 三角

総説および総合論文

シクロファンー人エレセプター・人工酵素としての分子認識能

村 上

幸人

クラウンエーテル・クリプタンド

菊池純一

佐々 木茂貴

修飾シクロデキストリンの化学

古 賀 憲 司

ポルフィリンに扔ける分子認識

池田博

戸田不二緒

機能性カリックスアレーンの合成と分子認識作用

生 越

久靖

黒田

裕 久

有 村

隆 志

新 海

松田

征 治

二分子膜

石川

勗

国 武

生体系におけるホストーゲストケミストリー：DNA の分子認識

雄 一

黒 田

バイオセンサー・・

軽 部

強誘電性液晶

城 野

福田

豊 喜

玲子

征 夫

正 博

木 村

敦 夫

「ホストーゲストケミストリー」についての総括・将来について

栄一

\section{十 字 路}

induced-fit 機構

村 上

幸人

クリプタン

古 賀

憲 司

キャピタンド

古 賀

憲 司

スフェランド

古 賀

憲 司

アトロプ異性

古 賀

憲 司

キャップ試薬

戸田不二緒

$\mu$ 一オキソ錯体

生 越

久靖

液晶-相転移- $\mathrm{T}$

石川

雄 一

ワトソンクリッフ型水素結合とフーグスティン型水素結合

黑 田

玲子

$\mathrm{A}, \mathrm{B}$ 型 DNA と Z 型 DNA

黑 田

玲 子

ロンドン分散力

黒 田

強誘電性 (体) / (非強誘電性)

福 田

玲子

新しい合成，REVINDEX，ほか 